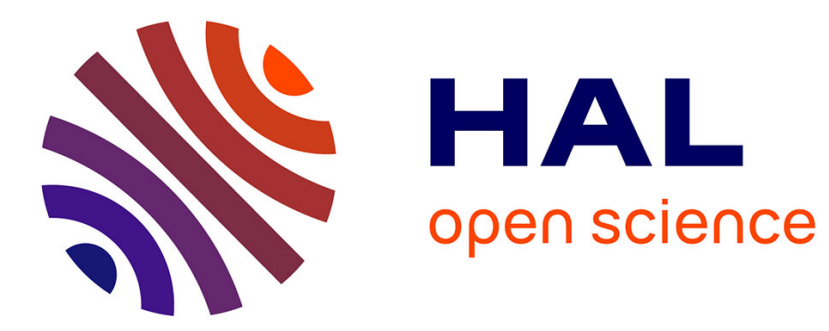

\title{
Public health law and the legal basis of public health
}

Adem Koyuncu, Wilhelm Kirch

\section{To cite this version:}

Adem Koyuncu, Wilhelm Kirch. Public health law and the legal basis of public health. Journal of Public Health, 2010, 18 (5), pp.429-436. 10.1007/s10389-010-0355-5 . hal-00562274

\section{HAL Id: hal-00562274 https://hal.science/hal-00562274}

Submitted on 3 Feb 2011

HAL is a multi-disciplinary open access archive for the deposit and dissemination of scientific research documents, whether they are published or not. The documents may come from teaching and research institutions in France or abroad, or from public or private research centers.
L'archive ouverte pluridisciplinaire HAL, est destinée au dépôt et à la diffusion de documents scientifiques de niveau recherche, publiés ou non, émanant des établissements d'enseignement et de recherche français ou étrangers, des laboratoires publics ou privés. 


\section{Desired Section: Original Article}

\section{Public Health Law and the Legal Basis of Public Health}

\section{Adem Koyuncu, Wilhelm Kirch*}

*Research Association Public Health Saxony, Faculty of Medicine, Technische

Universität Dresden, Fiedlerstr. 33, 01307 Dresden, Germany

\section{Corresponding Author}

Dr. med. Dr. iur. Adem Koyuncu (Corresponding Author)

Lawyer and Physician

Law Firm Mayer Brown LLP

Im Mediapark 8

50670 Köln, Germany

Tel.: +492215771100

Fax: +492215771 199

E-Mail akoyuncu@mayerbrown.com 


\section{SUMMARY}

\section{Subjects and Methods}

This article analyzes the scope of the rules which form the legal field "Public Health Law" and examines the characteristics of "Public Health Law". It further reviews the relationship between law and public health practice and analyzes the legal basis of public health. The article also examines the roles of the legal actors in public health practice and their means.

\section{Results}

Law grants the necessary powers to the states and governments and law also distributes these powers among the state institutions. Law and Public health build an important relationship in the interest of the population's health. Based on law and on legal authorization, states establish and fund public health agencies and bestow them with powers vis-à-vis citizens to pursue public health goals. A number of legal fields can be found which aim to protect and promote the public's health. The entirety of these legal fields build the superordinate field "Public Health Law". Public Health Law can be defined as the sum of all legal rules which directly or indirectly aim to safeguard or promote the population's health. These rules may result from statutory law, administrative regulations and acts, customary law and common law.

\section{Conclusions}

Law is essential for the infrastructure and functioning of public health. The legal basis of public health is rooted in the basic rights of the people to health, safety and life. Based on these basic rights, the people and the population they form have the right to self-defense. In states, people mandate the state and the state powers to safeguard and promote their health. Therefore, the population's basic right to health, safety and life and their corresponding right to self-defense are the basis and justification for the general existence of public health activities of states. Public health is a duty of the state vis-à-vis the people from whom all state powers derive.

\section{KEYWORDS}

Public Health Law, Law, Public Health, Legal Basis of Public Health 


\section{BACKGROUND}

Public health and law are interdependent. In practice, they are also strongly interwoven. This article elaborates on the important relationship between public health and law. The analysis of the interrelationship between public health and law documents that the theory and practice of public health significantly relies on law (Parmet, 2007).

Public health services aim to protect and promote the population's health. The scope of public health services is as manifold as the potential public health risks (Kirch, 2008). Prominent fields of public health include infectious disease prevention, occupational safety, regulation of products and environmental health. In addition, public health also comprises services with respect to public health information, health promotion activities, emergency services as well as social security and health insurance laws.

Corresponding to the broad scope of public health activities, public health systems need a sufficient legal fundament that allows the establishment of a public health infrastructure (e.g., public health agencies, authorities, organizations) and equips the public health agencies with legal authorizations to pursue their mission in the population's health interest. Public health depends on the existence and functioning of administrative public agencies (e.g., health departments). The creation of such agencies needs a legal basis as they can only be created and funded by virtue of legal authorization. In conclusion, law is necessary to build the infrastructure of public health and to ensure its proper function.

The broad scope of public health services also requires considerable financial funding which itself needs to be authorized by law. Public health is not free of cost. As to the financial funding of public health systems, law grants the state the power to establish public health systems and to fund them with financial resources. Thus, the state is entitled to spend the tax money for public health purposes like, for example, the procurement of vaccines against the swine flu pandemic.

Further, in addition to the financing of public health, it is also crucial that public health actions regularly affect individual rights and freedoms of affected individuals (e.g., by mandatory isolations of individuals). Therefore, such actions need a sufficient legal authorization so that the legal authorization makes such actions possible. Law indeed makes public health possible.

\section{METHOD}

This article analyzes the scope of the rules which form the "Public Health Law". It further examines the characteristics of "Public Health Law" and its relation to Public Health Practice. The article further analyzes the legal basis of public health and 
examines the roles of the legal actors in public health practice. In addition, the public health related legal means of these actors will be determined and analyzed in order to obtain a general view on the legal fundament of public health practice.

\section{RESULTS}

As indicated in the introduction, public health needs a legal fundament. Law is of vital importance to the practice and theory of public health. Thus, law is described as the "chief tool of public health" (Parmet, 2007) and as "fundamental to the practice of public health" (Lopez \& Frieden, 2007). Other scholars comment that law is "indispensable to the public's health" (Moulton et al., 2002) or as "vital to public health" (Gostin et al., 2007). In fact, "law makes public health possible" (Koyuncu, 2008a).

Many of the milestone achievements of public health would not have been accomplished without the significant contributions of law. When reviewing the ten great public health achievements in the $20^{\text {th }}$ century in the United States (CDC, 1999), it appears obviously that law has considerably contributed to all of these milestone successes (Moulton et al., 2007; Koyuncu, 2008a).

\section{Public Health Law}

The various fields of public health are governed and framed by corresponding specific legal fields. For example, the infectious disease prevention laws govern the practice of infectious disease prevention. These laws regulate, among others, the necessary legal frame of infectious disease prevention, the establishment of respective competent authorities and public agencies and set forth the administrative, technical, medical and legal means that can be used in practice infectious disease prevention. Similar regulations are laid down in other legal fields that govern public health aspects, for example, the occupational safety laws, environmental health laws which all are legal areas that govern and frame the practice of certain fields of public health.

There is a large number of legal fields that have been enacted to protect and promote the public's health. The entirety of these legal rules build the superordinate legal field "Public Health Law". In this sense, public health law can be defined as follows:

"Public health law is the sum of all legal rules which directly or indirectly aim to safeguard or promote the population's health. These rules may arise from statutory law, administrative regulations and acts, customary law, case-law and common-law. Public health law also includes laws which provide for the establishment and funding of corresponding administrative agencies" (Koyuncu, 2008a). 
This article is not aiming to discuss the details of public health law and its single legal fields. (See Koyuncu, 2008b, Koyuncu, 2008c, Koyuncu, 2008d elaborating on particular fields of public health law). However, some relevant characteristics of Public Health Law and its relation to public health practice deserve some particular attention.

\section{Public Health Law and Public Health Analysis}

As a general remark, it is noteworthy that as a tool of public health, law is complementary with the scientific tools of public health like epidemiology or statistics. These form the scientific-analytical part of public health and are commented as "public health analysis" (See Hall, 2003). In addition, public health practice has a legalregulatory part encompassing the regulatory infrastructure as well as the legal

authorities. The latter are referred to as "public health authority" (Hall, 2003). Public health law focuses and supports the legal-regulatory branch of public health practice. Both "public health analysis" and "public health authority" are necessary for the pursuit of public health activities.

\section{Practical Importance for Practitioners}

Public Health Law is not only relevant for lawyers and legal scholars but also for public health practitioners and public health agencies. As law authorizes and limits the practical means of public health practitioners and public health agencies, both groups should understand the role of Public Health Law. They should also become familiar with how "the law" is made, interpreted and enforced. This would enable them to use the legal means in their daily public health practice a much more targeted way and, in addition, also to influence the development of public health policy and public health law (Grad, 1990).

In many jurisdictions and from various perspectives, there is a "renewed interest in public health law" (Coker \& Martin, 2006).

\section{Legal Basis of Public Health}

In the following, we will elaborate on the legal basis of public health and the respective legal actors in public health practice. In addition, the public health related legal means of these actors will also be highlighted so that a general view on the legal fundament of public health practice is possible.

\section{The Population and Public Health}


Public health is not an end in itself. Public health is an obligatory service and duty of the state vis-à-vis the people from whom all state powers derive. The state has to establish public health systems in order to provide public health services to safeguard and promote the population's health. The legal basis of public health is rooted in the rights of the people (and the population they form) to health, safety and life and - based on these basic rights - their right to self-defense against health and safety risks. The people delegate their rights and mandate the state through the state constitution to safeguard and promote their health and to protect them from risks and harm. Therefore, the people's and the population's rights to health, safety and life and their rights to selfdefense are the basis and justification for the existence of public health activities.

To install a public health system and coercively enforce public health actions vis-à-vis individuals or corporations, the state needs sufficient legal powers and authorizations. The main public health related powers derive from the state's constitution that itself derives from the people. Each individual has the right to health, safety and life and as a matter of self-defense the right to protect himself from such harm. Correspondingly, populations which represent the sum of these individuals, also have the right to protect themselves from health threats. In addition, the population - as each individual - has the right to take measures to promote its health. In democracies, populations delegate these rights and powers to the state and the state organs. All state powers derive from the people. The population's right to self-defense from harm and its right to promote its health are delegated to the state. Therefore the state becomes in charge of protecting and promoting the population's health. To fulfill the duties resulting from this task, the states establish public health systems and practice public health.

\section{The State Powers and Public Health}

The state is the guardian of the common welfare and the individual rights. Therefore, it has the constitutional duty and powers to take appropriate measures to safeguard and promote the population's health. These powers are (in some jurisdictions) known as the "police powers" or as the "danger defense powers" (in German speaking jurisdictions as "Gefahrenabwehrrecht"). The legal term "police powers" denotes the powers of states designated to avert dangers and to defend the population from harm as well as from violations of law and order. Based on the police powers, the state and its institutions are entitled to take measures to protect the people and the legal and social order. The police powers authorize the state to take the public health measures necessary to eliminate dangers for the population. The police powers also authorize the state to take primarily paternalistic coercive measures vis-à-vis persons even though the affected persons have objections against these actions (e.g. protection of mentally ill persons by compulsory hospitalization or treatment). 
In addition to the police powers, state powers to safeguard and promote the public's health also derive from the constitutional power to regulate commerce and trade and the powers to collect taxes and the budget power including the power to spend (Grad, 1990, Gostin, 2000). These additional state powers provide effective control tools as well as behavior influencing means in the interest of the community's health and safety. For example, the power to control commerce allows the legal regulation of businesses and products. It also enables the legal regulation of professions which is an important tool particularly in the realm of public health (e.g., legal regulation of health professionals). The power to regulate trade allows to control and restrict the import of harmful goods.

The tax power is another strong instrument to influence behavior of individuals and corporations or public municipalities. Through tax law, the state can create incentives for a certain behavior that is regarded as favorable for the public's health. The state may also impose additional taxes on harmful products and, in doing so, influence the population's behavior (e.g., taxes on alcohol, cigarettes). Complementary to the tax power, the state has the power to spend. For example, the Constitution of the United States of America authorizes the U.S. Congress (i.e., the U.S. legislator) to make "expenditures expressly for the public's health, safety, and well-being" (Gostin, 2000). Similar laws that authorize the state to spend tax payer's money for public health purposes exist in most jurisdictions. For example, recent discussions in Germany on the cost of the procurement and administration of vaccines against swine flu highlight the importance of a clear legal regulation that allows (and/or obliges) certain state institutions to procure such vaccines and, in so doing, make expenditures in the interest of the public's health.

Overall, the police powers, the power to regulate commerce, trade and to collect taxes and the power to spend equip the state with strong legal and practical means. In addition, constitutions regularly grant further powers to the state with additional means to directly or indirectly protect and promote the public's health. This particularly includes the deriving powers to regulate other fields like occupational safety, environmental law, tort law, infectious diseases law, criminal law, traffic safety law and social insurance laws (health insurance, worker's compensation).

\section{The State Organization and the Constitution}

All state powers derive from the people, thus the population. This assignment of powers is realized via the state's constitution. The constitution is the basic and foundational legal document of a state. Via the constitution, the people set forth their state organization and nominate the state organs and create state institutions. Through the constitution, the legal system and infrastructure of a state is arranged by the people. In addition, the constitution assigns powers to the state institutions and provides for the legal responsibilities, authorities, duties and the scope of the powers granted to the state 
institutions. The constitutions also codify the people's rights (so-called constitutional or basic rights) and their legal status vis-à-vis the state and the political system. In doing so, constitutions protect the individuals' sphere and limit the exercise of powers by the state. The exercise of all state powers must be in compliance with the underlying scope and limits as defined in the constitution.

As a fundamental element of democratic jurisdictions, constitutions provide the basis for the state organization and the powers allocated at the state institutions. As such, most constitutions institute a so-called "separation of powers" in the country. This separation subdivides the state powers into three fractions: (1) the legislative power, (2) the executive power, and (3) the judiciary power. This separation of powers is called the "horizontal separation of powers".

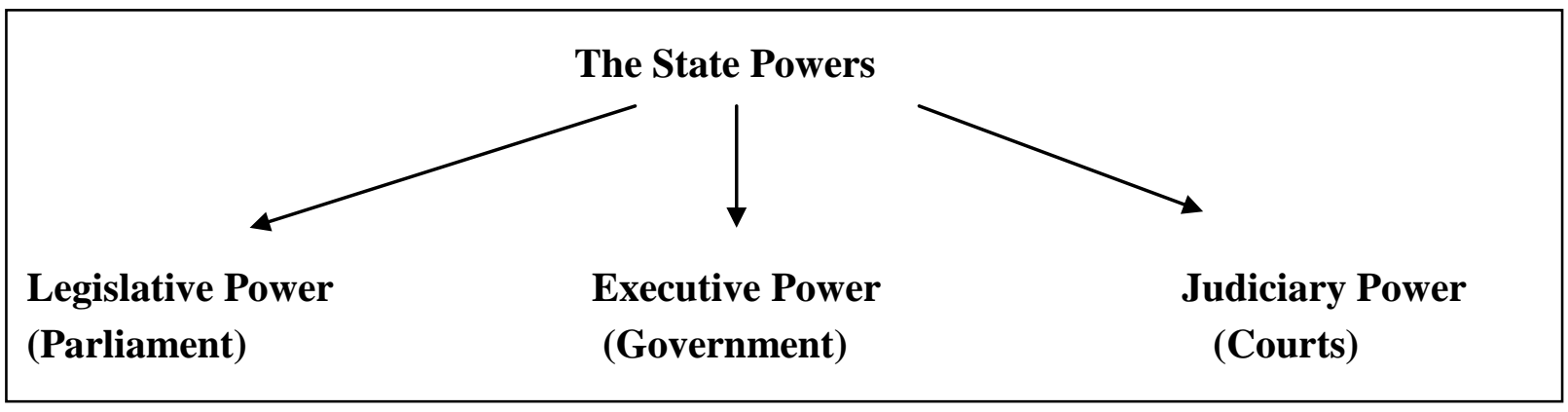

Figure 1. The Horizontal Separation of Powers

In addition to the horizontal separation of powers, in most jurisdictions there is also a "vertical separation of powers". The vertical separation of powers differentiates between (1) the Federal State Powers, (2) the Powers of a single state (if such single states exist), and (3) the Powers of local municipal governments (so-called "selfadministration").

The separation of powers aims to avoid a concentration of powers in one institution and shall establish a system of checks and balances among the institutions (See also Gostin, 2000). The constitutional state organization with the separation of powers and the attribution of responsibilities among state institutions is relevant for the understanding of how public health is practiced and which roles the state institutions have to play. Thus, constitutions arrange - on a general level - the legal responsibilities, duties and the scope of the powers granted to state institutions. On a more detailed level, the specific public health laws clarify the responsibilities, competencies and tools of the public health actors in a particular field of public health (e.g., occupational safety).

With respect to the vertical separation of powers, law has to assign responsibilities among the three levels of the said powers and arrange rules as to when federal 
competencies preempt state competencies. This is among others relevant to ensure rescue and emergency preparedness and to create order before catastrophes happen. Law has to make order and clarify which institution is in charge and who is entitled to give instructions to other institutions. Thus, public health laws must lay down which of the vertical powers is responsible to handle a certain public health issue, e.g., to cope with a pandemic. In some cases it will be necessary that the three powers interact and proceed jointly to avert risks. Also for such cases, public health laws must arrange a functioning public health system that is built of rules which set forth the competencies of the administrative institutions on the federal, state, and municipal level. Correspondingly, legal rules are necessary to provide guidance in case of conflicting laws between the powers and their institutions (e.g., by a clear hierarchy of laws).

\section{Legal Means and Actors in Public Health}

The legal means of public health denote the instruments applied in public health practice which are provided by law. In contrast to the legal means, public health practice also applies scientific means rooted (among others) in epidemiology, medicine, microbiology, of statistics. The range of legal means includes legal rules and statutes enacted by the legislator as well as individual administrative orders or court decisions to protect the public's health (See Koyuncu, 2008e with an overview of the legal means in public health practice).

The legal actors who play significant roles in public health practice can be differentiated along the line created by the constitutional separation of powers. As such, main actors are the legislator, the state government with its administrative institutions and the courts which represent the judiciary power. A further distinction is possible between the acting institutions on the federal level, the single state level and the municipal level. This latter distinction is obviously linked with the above described vertical separation of powers.

\section{The Legislator}

The legislator is the country's law-maker. Normally, the parliament is the legislator. (Other appellations instead of parliament are used depending on the jurisdiction, e.g. "Congress" or "National Assembly", etc.). Through law-making, the legislator is able to build the fundament of public health practice. The parliament enacts statutes (e.g., bills or acts) and creates and funds state institutions. In addition, the legislator has the power to collect taxes, to budget and to spend so that major decisions on expenditures depend on the parliament. The legislation has to follow a specific procedure which is described in the constitution. Among others, the law-making process regularly has to include public hearings. For special aspects, the legislator will have to ask for practitioners' 
views. This means that for public health related legislation, the legislator will regularly have to involve public health agencies and their specialists.

\section{Legal means of the Legislator:}

The legislator disposes of a broad range of powerful legal means. The legislator may particularly use the following means. First of all, the legislator may enact statutes assuring and promoting public health purposes (e.g., laws regulating occupational safety, etc.). The legislator may enact statutes defining public health terms (e.g., the legislator may define the scope of the term the state's "catastrophe" what then determines the situations in which certain public health actions are allowed). The legislator may enact statutes which lay down policy objectives.

As an important point, the legislator may also enact laws that have an indirect effect on public health (e.g., tax law, criminal law, tort law). As a powerful tool, the legislator may grant legal authorization to the government and in so doing, enable the government to exercise public power and encroach personal or property rights. To ensure that the government and the administration duly respect the population's personal rights, it is also up to the legislator to enact laws that guarantee procedural rights within the public health administration.

Further, the legislator is entitled to create and define the mission of administrative institutions like public health agencies and to grant funds to the government and the administrative agencies to spend for public health actions. In order to ensure the adequate interaction among the governmental and administrative institutions, the legislator will regularly enact laws that define the competencies and the interrelation between these institutions. Obviously, the legislator disposes of a large variety of effective instruments in order to safeguard the public's health. This is not surprising as the protection of the population from health and safety risks is probably the most important duty of the state and its institutions.

\section{The Government and Administrative Agencies}

The government is the executive power in the state. It is the administrating state power and therefore the central actor with respect to public health actions and public health law. As the executive power, the government is the central addressee of the people's (i.e., the population's) mandate to protect their health and safety. Already, the Virginia Declaration of Rights from 1776 stated "[T]hat government is, or ought to be, instituted for the common benefit, protection, and security of the people, nation or community; of all the various modes and forms of government that is best, which is capable of producing the greatest degree of happiness and safety...". Again, it deserves emphasis that the government is the central actor of public health practice. Probably, it is the most important obligation of the government to protect the public health and safety. 


\section{Legal means of the Government and Administration}

The government and the administrative agencies presumably have a large number of legal means at their disposal. The government is heading the state's administration. It oversees numerous administrative institutions among which there are regulatory and non-regulatory agencies. In its function, the government delegates powers to these administrative agencies so that they are bestowed with sufficient powers to accomplish their mission.

The governments are entitled to draft and promulgate regulations. Administrative regulations are not statutory laws but they nevertheless install legally binding rules. They commonly specify general or abstract legal terms and rules (e.g., the scope of the term "current state of the art"). To do so, the government and its agencies have the right to set standards and rules (e.g., for the maximum concentration of certain substances in the air). The setting of standards and rules is an intensively used tool, particularly, in the fields of environmental law and occupational safety law. The government can also issue ordinances and define limits to particular activities (e.g., air pollution ordinances, zoning ordinances). Such ordinances and regulations are also useful means to set standards and guidelines (e.g., noise and pollution level thresholds).

Further, the government and the administrative agencies are entitled to issue administrative orders to regulate individual cases. An administrative order is a core legal tool of the state administration (i.e., the government and its administrative agencies). An administrative order is a physical act or a decision issued by the administration that is determined to regulate and resolve a specific case and to mitigate a public health risk (e.g., by ordering the isolation of a person with swine flu). Such administrative acts unfold direct legal effects vis-à-vis the individual addressee. Administrative acts, among others, include public health agency decisions which order a quarantine, the isolation of a person, the closure of a business place, the abatement of a nuisance, or the revocation of a professional licence.

As a crucial and efficient tool, the government may create further administrative agencies that oversee certain fields of public health (e.g. the Food and Drug Administration (FDA) in the U.S.A.). These agencies act as regulatory supervision authorities and are involved in the market surveillance. The agencies are also entitled to collect data and to monitor public health threats. The administrative agencies in charge of particular public health areas (e.g., the national environment protection agencies) may release and enforce administrative acts and perform administrative physical acts to immediately defend the public from health or safety risks (e.g., the competent regulatory agency may order the recall of a product, the administration may order the closure of a business place). 
Government and administrative agencies are also in a legal position to release public information which includes health promotion campaigns (e.g., the campaigns against smoking or campaigns for safer sex). Moreover, these institutions are also entitled to issue public warnings against risks to the public health (e.g., warnings against product risks or environmental risks, etc.).

Further, the administrative agencies may impose sanctions and administrative fines against public health offenders. The possibility to impose such sanctions additionally entails a deterrent effect to potential offenders. Administrative agencies may also ask prosecutors to initiate criminal investigations or prosecution against public health offenders so that they may become subject to criminal punishment (See also Koyuncu, 2008f).

The government may also use the military which as an organization is subordinated under the government. The military is mainly used in very critical situations (like natural disasters) and large -scale emergencies so that in such nationwide critical situations the military can also contribute to the public's health (Matthews et al., 2007).

\section{The Courts as Judiciary Power}

A democratic state organization has to rely on an independent judiciary power. The courts represent this judiciary power. The function of courts is to review laws and interpret the legal rules stipulated in these laws. In doing so, courts enforce existing laws and they resolve legal conflicts. They may also repeal laws as invalid. Courts are crucial for the enforcement of laws and they may be called by individuals and administrative agencies if a preliminary injunction is necessary to cope with an acute threat.

As an exclusive authority in the state, only courts are authorized to sentence a person to criminal punishment. Courts may grant remedies if individuals were improperly affected by the state institutions, e.g., for an improper compulsory medical treatment. They may also stop administrative actions and, thus, limit the power of the government.

Basically, the judiciary power's primary function is to judge legal disputes by reviewing, interpreting and enforcing laws and, in doing so, the judiciary power shall provide guidance to the public and to individuals. As outcomes of court proceedings, courts release judgments, intermediate and preliminary injunctions and impose penalties. These are their central legal means. With these means, they establish case law what is particularly important for those legal areas where the legislator missed to enact codified laws. In addition to such case-related work, courts influence legislatures and policies. As scholars correctly note, several policies of contemporary public health are 
the result of an "interactive dialog between courts and the legislatures" (Parmet \& Daynard, 2000).

Courts have influenced public health practice also through other ways. Where statutory laws were lacking sufficient rules, courts have developed legal doctrines by case-law. This has taken place in most jurisdictions worldwide and not only in the common-law countries (See as example for tort law McClurg et al., 2007). In doing so, courts have provided guidance for the population and the administrative agencies and the individual public health officials. Overall, courts and judges have contributed and still contribute significantly to the assurance and promotion of the public's health. The judiciary's influence avenues in public health practice must not be underestimated. Rather, the courts' importance in contemporary public health is even more increasing.

\section{Other Actors in Public Health Practice}

Public health is not only practiced or influenced by (public) state institutions. In addition, further actors who are based in the private sector or in the non-profit-sector also play important roles in contemporary public health practice. As such, governments and administrative agencies regularly involve private service providers into the supply of public health services. Such cooperations need to be based on an underlying legal authorization that is commonly granted through a contract. For example, private ambulance service providers are included in the provision of rescue and emergency services to the population even though these services are public duties of the state. Thus, the state may delegate the operative handling of some of his public duties to private sector players.

Non-governmental and non-profit organizations also play a relevant role in contemporary public health. They contribute through different paths to the public health. They regularly fill a gap in public health practice as they often operate in areas where state institutions have withdrawn from. Further, for the public health practice international organizations with public health missions are also relevant. For example, the World Health Organization (WHO) is a worldwide player in the support of state institutions in their of public health activities. The WHO acts on a superordinate level as the it has to oversee transnational public health threats. If it is taken into account that the WHO is funded by the states, it becomes clear that by constituting such superordinate agencies, the states ensure that they are also safeguarded from international public health risks. The WHO is the institution which is mandated by the individual states to oversee these risks and to coordinate the protective measures. In addition to the WHO, other worldwide acting organizations like e.g. the United Nations Environment Program (UNEP), play important roles in a more and more globalized world with correspondingly more and more globalized public health threats. The legal handling of global public health activities will require the further interaction of such global 
organizations but also the legal foundation (e.g., international agreements, public international law) what might lead to a modification of the legal basis of public health (Fidler \& Cetron, 2007).

Finally, to some extent, public health can also be promoted by individuals. Regarding legal options, individuals can influence public health relevant developments by private litigation against, for example, companies, state authorities, and medical service providers. As a new type of lawsuits, in recent years cases are brought to court where individuals request the administration to take public health action to cope with a certain public health risk. As such, in Germany a city government was convicted by the Federal Administrative Court (Bundesverwaltungsgericht) to take sufficient public health measures to reduce the air pollution with dangerous micro dust particles in a certain area of a large city. This type of lawsuit can be filed by private persons or by public health advocacy organizations. Such legal actions aim to protect and promote the public's health by calling for safeguarding administrative action which the administration refuses to initiate by itself. The practical importance of such legal instruments to influence particular public health issues is increasing.

Further, product liability litigation initiated by private persons has contributed to the improvement of the product safety levels as well as the manufacturers' duties to inform and instruct customers, or the industry standards to quality management, keeping records and monitoring safety aspects (McClurg et al., 2007; Parmet \& Daynard, 2000; Gostin, 2000). Another exemplary area is medical malpractice litigation filed by individuals against medical doctors and hospitals. These lawsuits have improved the patient's legal position and rights vis-à-vis the medical doctors (See for German law Koyuncu, 2007; Koyuncu, 2006a). Such lawsuits and the doctrines developed by courts as result of them have also promoted the patient empowerment, and therefore, have additionally contributed to the public's health in addition to the deterrent perspective for doctors and hospitals to become liable (Koyuncu, 2006b). Private lawsuits or criminal proceedings can also unfold impact on public health topics as there are several contact points between public health and criminal law and between public health and private law (See Koyuncu 2008f (Criminal Law and Public Health) or Koyuncu, 2008g (Tort Law and Public Health) with detailed annotations).

\section{CONCLUSIONS}

The goal of this article was to describe the legal basis of public health and to underscore the importance of Public Health Law as a distinct legal field. A large number of legal fields are in effect to protect and promote the public's health. The entirety of these legal regulations build the superordinate legal field "Public Health Law" which is defined as follows: 
"Public health law is the sum of all legal rules which directly or indirectly aim to safeguard or promote the population's health. These rules may arise from statutory law, administrative regulations and acts, customary law, case-law and common-law. Public health law also includes laws which provide for the establishment and funding of corresponding administrative agencies" (Koyuncu, 2008a).

The legal basis of public health is rooted in the basic rights of the people (and the population they form) to health, safety and life. Based on these basic rights, the people and the population they form have the right to self-defense. In states, the people mandate the state organizations and the state powers to safeguard and promote their health and to protect them from harm. Therefore, the population's basic right to health, safety and life and their corresponding right to self-defense are the basis and justification for the general existence of public health activities. Public health is a duty of the state vis-à-vis the people from whom all state powers derive. The state has to establish public health systems in order to safeguard and promote the population's health.

There is a strong interdependency between law and public health (Parmet, 2007). Law and public health are interwoven. Public health practice relies on law as law grants the necessary powers to the states and governments and law also distributes these powers among the state institutions. Based on the legal authorization, states establish and fund public health agencies. Law also bestows the public health administration with coercive powers vis-à-vis citizens to pursue its public health mission. Therefore, law is essential for the public health infrastructure and for the effective functioning of public health in practice.

\section{STATEMENT ABOUT CONFLICT OF INTEREST:}

The authors declare no conflict of interest.

\section{REFERENCES:}

CDC (1999) Ten great public health achievements - United States, 1900-1999. MMWR;48:241-243

Coker R, Martin R (2006) Introduction: The importance of law for public health policy and practice. Public Health;120:2-7

Fidler DP, Cetron MS (2007) International Considerations. In: Goodman RA, Hoffmann RE, Lopez W, Matthews GW, Rothstein MA, Foster KL (eds) Law in Public Health Practice, $2^{\text {nd }}$ edn. Oxford University Press, New York, pp. 168-195 
Gostin LO (2000) Public Health Law: Power, Duty, Restraint. University of California Press and The Milbank Memorial Fund, Berkeley and New York

Gostin LO, Jacobson PD (2006) Law and the Health System. Foundation Press, New York

Gostin LO, Thompson FE, Grad FP (2007) The Law and the Public's Health: The Foundations. In: Goodman RA, Hoffmann RE, Lopez W, Matthews GW, Rothstein MA, Foster KL (eds) Law in Public Health Practice, $2^{\text {nd }}$ edn. Oxford University Press, New York, pp. 25-44

Grad FP (1990) The Public Health Law Manual, 2 ${ }^{\text {nd }}$ edn. American Public Health Association, Washington DC

Hall MA (2003) The Scope and Limits of Public Health Law. Perspect Biol Med;46:S199-S209

Kirch W (ed) (2008) Encyclopedia of Public Health. Springer, New York

Koyuncu A (2008a), Public Health Law. In: Kirch W (ed) Encyclopedia of Public Health, Springer, New York, pp. 1186-1198

Koyuncu A (2008b) Environmental Law and Public Health. In: Kirch W (ed) Encyclopedia of Public Health, Springer, New York, pp. 334-338

Koyuncu A (2008c) Labor and Occupational Safety Law. In: Kirch W (ed) Encyclopedia of Public Health, Springer, New York, pp. 827-830

Koyuncu A (2008d) Infectious Diseases Control Law. In: Kirch W (ed) Encyclopedia of Public Health, Springer, New York, pp. 770-774

Koyuncu A (2008e) Public Health Law, Legal Means. In: Kirch W (ed) Encyclopedia of Public Health, Springer, New York, pp. 1201-1205

Koyuncu A (2008f) Criminal Law and Public Health. In: Kirch W (ed) Encyclopedia of Public Health, Springer, New York, pp. 177-180

Koyuncu A (2008g) Tort Law and Public Health. In: Kirch W (ed) Encyclopedia of Public Health, Springer, New York, pp. 1397-1401 
Koyuncu A (2007) Das System der zivilrechtlichen Arzthaftung in Deutschland. Arzt Zahnarzt Recht;19:69-76

Koyuncu A (2006a) Der pharmaceutical informed consent. Das Modell zur Aufklärung und Information des Patienten vor der Arzneitherapie. Pharma Recht 2006;28:343-348

Koyuncu A (2006b) Prävention und Eigenverantwortung. In: Kirch W Badura B (eds) Prävention. Springer, Heidelberg, pp. 121-139

Koyuncu A (2004) Das Haftungsdreieck Pharmaunternehmen - Arzt - Patient. Verschulden und Mitverschulden bei der Haftung für Arzneimittelschäden. Springer, Berlin

Lopez W, Frieden TR (2007) Legal Counsel to Public Health Practitioners. In: Goodman RA, Hoffmann RE, Lopez W, Matthews GW, Rothstein MA, Foster KL (eds) Law in Public Health Practice, $2^{\text {nd }}$ edn. Oxford University Press, New York, pp. 199221

Matthews GW, Abbott EB, Hoffman RE, Cetron ME (2007) Legal Authorities for Interventions in Public Health Emergencies. In: Goodman RA, Hoffmann RE, Lopez W, Matthews GW, Rothstein MA, Foster KL (eds) Law in Public Health Practice, $2^{\text {nd }}$ edn. Oxford University Press, New York, pp. 262-283

Moulton AD, Goodman RA, Parmet WE (2007), Perspective: Law and Great Public Health Achievements. In: Goodman RA, Hoffmann RE, Lopez W, Matthews GW, Rothstein MA, Foster KL (eds) Law in Public Health Practice, $2^{\text {nd }}$ edn. Oxford University Press, New York, pp. 3-21

Moulton AD, Goodman RA, Cahill K, Baker EL (2002) Public Health Legal Preparedness for the $21^{\text {st }}$ Century. J Law Med Ethics;30:141-143

McClurg AJ, Koyuncu A, Sprovieri LE (2007) Practical Global Tort Litigation. U.S, Germany and Argentina. Carolina Academic Press, Durham

Parmet WE (2007) Introduction: The Interdependency of Law and Public Health. In: Goodman RA, Hoffmann RE, Lopez W, Matthews GW, Rothstein MA, Foster KL (eds) Law in Public Health Practice, $2^{\text {nd }}$ edn. Oxford University Press, New York, pp. xxviixxxvii.

Parmet WE, Daynard RA (2000) The New Public Health Litigation. Annual Review of Public Health;21:437-454 
Reynolds C (1995) Public Health Law in Australia. The Federation Press, Annandale Teret SP (1986) Litigating for the Public's Health. Journal of Public Health;76:1027 